\title{
KEBIJAKAN DIVIDEN, HUTANG, DAN PROFITABILITAS TERHADAP NILAI PERUSAHAAN
}

\author{
Pery Sutisna \\ perysutisna@gmail.com \\ Jaja Suteja \\ Universitas Pasundan \\ Jl. Tamansari No. 6-8, Bandung 40116
}

diterima: 20/12/2019; direvisi: 26/1/2020; disetujui: 28/4/2020

\begin{abstract}
Firm value was a goal that must be achieved in the context of the welfare of shareholders. The objective of this research was to investigate the effect of dividend policy, debt policy, and profitability to firm value of property and real estate industries in 2012-2016. Population of this research was property and real estate companies listed in Indonesia Stock Exchange (IDX). The sampling method used was purposive sampling and the results were 10 companies according to the criteria of the sample. Method analysis using pooled regression. The results showed that dividend policy, debt policy, and profitability have significant effect to firm value simultaneously. Partially, dividend and debt policy have not significant effect to the firm value partially, but profitability has significant effect.
\end{abstract}

Keywords: dividend policy; debt policy; profitability; firm value; pooled regression

\begin{abstract}
Abstrak
Nilai perusahaan merupakan tujuan yang harus dicapai dalam rangka kesejahteraan para pemegang saham. Penelitian ini dilakukan untuk mengetahui pengaruh kebijakan hutang, profitabilitas dan kebijakan dividen terhadap nilai perusahaan pada sektor properti dan real estate periode 20122016. Populasi adalah perusahaan properti dan real estate yang terdaftar di Bursa Efek Indonesia (BEI). Metode pemilihan sampel adalah purposive sampling dan didapat 10 perusahaan yang sesuai dengan kriteria sampel. Metode analisis data menggunakan regresi data panel. Hasil pengujian hipotesis menunjukkan bahwa terdapat pengaruh signifikan kebijakan dividen, kebijakan hutang dan profitabilitas terhadap nilai perusahaan secara simultan. Secara parsial kebijakan dividen dan kebijakan hutang tidak memiliki pengaruh signifikan terhadap nilai perusahaan, sedangkan profitabilitas berpengaruh signifikan.
\end{abstract}

Kata Kunci: kebijakan dividen; kebijakan hutang; profitabilitas; nilai perusahaan; regresi data panel 


\section{PENDAHULUAN}

Perusahaan memiliki tujuan untuk memaksimalkan kesejahteraan pemilik melalui kebijakan keuangan yaitu, keputusan pendanaan, investasi, dan manajemen aktiva. Para manajer diharapkan akan bertindak atas nama pemilik, yakni memaksimumkan nilai perusahaan sehingga kemakmuran pemilik akan dapat tercapai khususnya pada perusahaan property dan real estate.

Nilai perusahaan merupakan cerminan terhadap harga yang harus dibayar oleh investor, harga saham yang tinggi membuat nilai perusahaan juga tinggi. Memaksimalkan nilai perusahaan berarti juga memaksimalkan kemakmuran pemegang saham. Maksimalisasi nilai perusahaan dapat dicapai bila memperhatikan para pemangku kepentingan (stakeholder). Keseimbangan pencapaian tujuan stakeholder, dapat menjadikan perusahaan berpeluang mendapatkan keuntungan optimal sehingga kinerja perusahaan akan dinilai baik oleh investor (Jusriani \& Rahardjo, 2013).

Beberapa rasio yang digunakan untuk mengukur nilai perusahaan selain melihat dari harga saham di pasar, salah satunya yaitu dengan Price Book Value (PBV). Keberadaan PBV lebih sering digunakan investor dalam menilai perusahaan dan penting untuk menentukan strategi investasi di pasar modal, karena dapat memprediksi saham yang overvalued atau undervalued.

Faktor pertama yang mempengaruhi nilai perusahaan adalah kebijakan dividen. Kebijakan dividen merupakan kebijakan yang memutuskan apakah perusahaan akan mendistribusikan laba yang diperoleh kepada pemegang saham dalam bentuk dividen tunai atau menahan laba tersebut untuk diinvestasikan kembali sebagai retained earnings (Gitman and Zutter, 2015).

Kebijakan dividen diukur dengan Dividend Payout Ratio (DPR) adalah rasio pertimbangan dari dividen yang telah dibayarkan terhadap laba per saham. Pembayaran dividen mencerminkan kondisi keuangan perusahaan dan memiliki dampak terhadap persepsi pasar. DPR akan menjadi salah satu pertimbangan investor dalam membeli dan menahan saham yang dimilikinya (Darmadji dan Hendy, 2012). Kebijakan dividen akan mempengaruhi harga saham (Enebrand \& Magnusson, 2018).

Kebijakan dividen merupakan suatu kebijakan untuk memutuskan apakah laba yang diperoleh akan dibagikan kepada pemegang saham sebagai dividen atau akan ditahan dalam bentuk laba ditahan untuk diinvestasikan kembali dengan tetap memperhatikan tujuan yaitu meningkatkan nilai perusahaan.

Menurut (Gitman and Zutter, 2015) kebijakan dividen merupakan kebijakan yang memutuskan apakah perusahaan akan mendistribusikan laba yang diperoleh kepada pemegang saham dalam bentuk dividen tunai atau menahan laba tersebut untuk diinvestasikan kembali sebagai retained earnings.
Sebagaimana yang dikemukakan oleh (Husnan dan Pudjiastuti, 2015) bahwa kebijakan dividen berkaitan dengan penggunaan laba yang menjadi hak pemegang saham. Pada dasarnya, laba tersebut bisa dibagi sebagai dividen atau laba yang ditahan untuk diinvestasikan kembali dengan tetap memperhatikan tujuan yaitu meningkatkan nilai perusahaan.

Rasio pembayaran dividen adalah rasio yang menunjukkan besarnya bagian laba bersih yang ditanamkan kembali atau ditahan di perusahaan dan diyakini berguna dalam mengestimasi pertumbuhan laba tahun mendatang. Metode pengukuran yang digunakan untuk mengukur kebijakan dividen adalah Dividend Payout Ratio (DPR).

Alasan digunakannya DPR ini seperti yang dikemukakan oleh (Mardiyati, et. al. 2012) gambarkan perilaku oportunistik manajerial yaitu dengan melihat berapa besar keuntungan yang dibagikan kepada pemegang saham sebagai dividen dan berapa yang disimpan di perusahaan.

Hasil penelitian (Rizqia, et. al., 2013), (Rahayu dan Asandimitra, 2014), (Mayogi, 2016), (Ochieng', 2016), (Murekefu \& Ouma, 2012) menyatakan kebijakan dividen berpengaruh terhadap nilai perusahaan. Demikian pula pernyataan (LDN, 2019) yang menyatakan dividen merupakan variabel yang cukup untuk menggambarkan kinerja perusahaan. Kebijakan dividen tidak hanya penting bagi pembuat keputusan, tetapi juga bagi investor untuk menentukan portofolio keuangannya, memiliki pengaruh terhadap harga saham (Yee, 2017).

Faktor kedua yang mempengaruhi nilai perusahaan adalah kebijakan hutang. Kebijakan hutang merupakan kebijakan pendanaan perusahaan yang bersumber dari eksternal. Kebijakan hutang menggambarkan hutang jangka panjang yang dimiliki untuk membiayai operasi perusahaan.

Kebijakan hutang sering diukur dengan Debt to Equity Ratio (DER) merupakan rasio yang digunakan untuk menilai utang dengan ekuitas. Rasio ini dicari dengan cara membandingkan seluruh hutang dengan ekuitas. Rasio ini digunakan untuk mengetahui jumlah dana yang disediakan peminjam (kreditor) dengan pemilik perusahaan. Dengan kata lain, rasio ini berfungsi untuk mengetahui setiap rupiah modal sendiri yang dijadikan untuk jaminan utang (Kasmir, 2015). Penggunaan hutang mengakibatkan pemegang saham dapat mengendalikan perusahaan dengan jumlah investasi ekuitas yang terbatas.

Kebijakan hutang termasuk kebijakan pendanaan perusahaan yang bersumber dari eksternal. Kebijakan hutang akan memberikan dampak pada pendisiplinan bagi manajer untuk mengoptimalkan penggunaan dana yang ada. Karena hutang yang cukup besar akan menimbulkan kesulitan kebangkrutan dan kesulitan keuangan. 
Menurut (Riyanto, 2011) kebijakan hutang adalah kebijakan yang diambil oleh pihak manajemen dalam rangka memperoleh sumber pembiayaan sehingga dapat digunakan untuk membiayai aktivitas operasi perusahaan.

Sedangkan menurut (Mardiyati, et. al, 2012) mengemukakan bahwa kebijakan hutang merupakan kebijakan tentang seberapa jauh sebuah perusahaan menggunakan pendanaan hutang. Semakin tinggi proporsi hutang maka semakin tinggi harga saham perusahaan.

Kebijakan hutang perusahaan menyangkut keputusan tentang bentuk dan komposisi pendanaan yang akan dipergunakan oleh perusahan. Sumber pendanaan dapat diperoleh dari dalam perusahaan (internal financing) dan dari luar perusahaan (external financing). Debt to Equity Ratio (DER) merupakan rasio yang mengukur perbandingan antara modal eksternal dengan modal sendiri.

Hasil penelitian (Rizqia, et. al., 2013) menunjukkan bahwa kebijakan hutang berpengaruh positif dan signifikan terhadap nilai perusahaan. (Rajesh, 2015) menyatakan bahwa semakin tinggi penggunaan hutang akan meningkatkan expected return bagi perusahaan.

Faktor ketiga yang mempengaruhi nilai perusahaan adalah profitabilitas. (Kasmir, 2015) menyatakan bahwa rasio profitabilitas merupakan rasio untuk menilai kemampuan perusahaan dalam mencari keuntungan. Rasio ini juga memberikan ukuran tingkat efektivitas manajemen. Penggunaan rasio profitabilitas dapat dilakukan dengan menggunakan perbandingan antara berbagai komponen yang ada di laporan keuangan, terutama laporan keuangan neraca dan laporan laba rugi. Tujuannya adalah agar terlihat perkembangan dalam kurun waktu tertentu, baik penurunan atau kenaikan profitabilitas yang dicapai perusahaan.

Profitabilitas adalah kemampuan suatu perusahaan dalam menghasilkan laba selama pereode tertentu pada tingkat penjualan, asset dan modal saham tertentu. Profitabilitas suatu perusahaan dapat dinilai melalui berbagai cara tergantung pada laba dan aktiva atau modal yang akan diperbandingkan satu dengan lainya.

Menurut (Kasmir, 2015) rasio profitabilitas merupakan rasio untuk menilai kemampuan perusahaan dalam mencari keuntungan atau laba dalam suatu periode tertentu. Rasio ini juga memberikan ukuran tingkat efektivitas manajemen suatu perusahaan yang ditunjukkan dari laba yang dihasilkan dari penjualan atau dari pendapatan investasi.

Return On Equity (ROE) merupakan salah satu variabel yang terpenting yang dilihat investor sebelum berinvestasi. ROE menunjukkan kemampuan perusahaan untuk menghasilkan laba setelah pajak dengan menggunakan modal sendiri yang dimiliki perusahaan. Investor yang akan membeli saham akan tertarik dengan ukuran profitabilitas ini, atau bagian dari total profitabilitas yang bisa dialokasikan ke pemegang saham. (Hanafi dan Halim, 2012).
Hasil penelitian (Rizqia, et. al., 2013) menunjukkan bahwa profitabilitas berpengaruh positif dan signifikan terhadap nilai perusahaan. (Rajesh, 2015) menyatakan bahwa laba yang semakin besar secara signifikan menciptakan nilai perusahaan.

Hasil penelitian (Thi, et. al., 2018) menunjukkan bahwa ukuran perusahaan, kebijakan dividen, kebijakan hutang, earning per share, likuiditas, dan profitabilitas berpengaruh signifikan terhadap nilai perusahaan.

Tujuan penelitian ini adalah untuk mengetahui perkembangan kebijakan dividen, hutang, profitabilitas, dan nilai perusahaan pada sektor properti dan real estate yang terdaftar di Bursa Efek Indonesia (BEI) periode 2012-2017 serta untuk mengetahui pengaruh kebijakan dividen, hutang dan profitabilitas terhadap nilai perusahaan. baik secara bersama-sama maupun parsial.

Hipotesis yang diajukan adalah kebijakan dividen, hutang, dan profitabilitas berpengaruh terhadap nilai perusahaan, baik secara simultan dan parsial.

\section{METODE}

Metode penelitian yang digunakan adalah deskriptif dan metode verifikatif. Sampel ditentukan dengan metode purposive sampling menggunkana kriteria: (1) Perusahaan jasa sektor properti real estate yang terdaftar di Bursa Efek Indonesia periode 2012-2017; dan (2) Membagikan dividen secara berturut-turut. Jumlah sampel adalah delapan belas (18), karena tiga puluh tujuh (31) lainnya tidak memiliki kelengkapan data untuk dianalisis dari jumlah populasi sebanyak (49) perusahaan. Data yang digunakan berupa data sekunder dengan model yang digunakan adalah regresi data panel.

\section{HASIL}

Perkembangan dari kebijakan dividen, hutang, profitabilitas dan nilai perusahaan sektor property dan real estate yang terdaftar di BEI periode 2012-2017 disajikan dalam Tabel 1. Kondisi kebijakan dividen dengan proksi DPR, dan nilai perusahaan dengan proksi PBV pada perusahaan properti dan real estate yang terdaftar di BEI periode 2012-2017 cenderung menurun. Kebijakan hutang dengan proksi DER dan profitabilitas dengan proksi ROE cenderung meningkat.

Berdasarkan Tabel 2, pengaruh kebijakan dividen, hutang, dan profitabilitas terhadap nilai perusahaan bentuk persamaan regresi data panel dengan model fixed effect adalah sebagai berikut:

$$
\begin{aligned}
\mathrm{Y}= & 1,954770-2,008363 \mathrm{X}_{1}+0,045368 \mathrm{X}_{2}+2,291998 \mathrm{X}_{3} \\
& +\mathrm{e}_{\mathrm{it}} \ldots \ldots \ldots .(1)
\end{aligned}
$$

Berdasarkan Tabel 2 dapat diketahui kebijkan dividen, kebijakan hutang, dan profitabilitas secara simultan berpengaruh signifikan terhadap nilai perusahaan sebesar $78,70 \%$. 
Berdasarkan Tabel 3, menunjukkan bahwa tidak terdapat pengaruh kebijakan dividen dan kebijakan hutang terhadap nilai perusahaan, sedangkan profitabilitas berpengaruh signifikan.

Koefisien determinasi parsial kebijakan dividen, kebijakan hutang, dan profitabilitas ditunjukan dapat dihitung pada Tabel 4. Profitabilitas merupakan variabel yang memiliki kontribusi terbesar terhadap nilai perusahaan sebesar $48,10 \%$.

\section{PEMBAHASAN}

Hasil pengujian menunjukkan bahwa secara simultan kebijakan dividen, kebijakan hutang, dan profitabilitas secara bersama-sama berpengaruh signifikan terhadap nilai perusahaan.

Hasil analisis regresi menunjukkan bahwa kebijakan dividen berpengaruh negatif dan tidak signifikan terhadap nilai perusahaan. Menurut information content of dividend theory investor akan melihat kenaikan dividen sebagai sinyal positif atas prospek perusahaan di masa depan, karena pembayaran dividen ini dapat mengurangi ketidakpastian dan konflik keagenan antara manajer dan pemegang saham. Ketika perusahaan membagikan dividen maka tingkat pertumbuhan akan berkurang. Di sisi lain apabila tidak membagikan dividen maka pasar akan memberikan sinyal negatif kepada prospek perusahaan.

Tidak adanya pengaruh kebijakan dividen terhadap nilai perusahaan, dapat dijelaskan secara teoritis dalam dividend irrelevance theory yang menyatakan bahwa kebijakan dividen tidak berpengaruh pada harga saham. Teori MM berpendapat bahwa nilai perusahaan ditentukan pada kemampuan perusahaan dalam memperoleh laba, bukan pada bagaimana laba tersebut dibagi menjadi dividen dan laba ditahan. Sehingga kebijakan dividen merupakan suatu yang tidak relevan untuk dipersoalkan. Teori MM menyatakan bahwa nilai suatu perusahaan tidak dipengaruhi oleh besar kecilnya dividend payout ratio, tetapi hanya ditentukan oleh profitabilitas dasar dan risiko usahanya, dengan asumsi bahwa tidak ada pajak yang dibayarkan atas dividen, saham dapat dibeli dan dijual tanpa adanya biaya transaksi, semua hak baik manajer maupun pemegang saham memiliki informasi yang sama tentang laba perusahaan di masa yang akan datang. menurut MM jika dividen dibagi atau ditahan tidak akan mempengaruhi nilai perusahaan, atau dengan kata lain kebijakan dividen tidak relevan.

Hasil ini sejalan dengan penelitian yang telah dilakukan oleh (Rehman, 2016); (Ayako \& Wamalwa, 2015), (Sofyaningsih dan Hardiningsih, 2011) yang menyatakan bahwa kebijakan dividen tidak berpengaruh signifikan terhadap nilai perusahaan.

Hasil ini tidak sejalan dengan penelitian yang telah dilakukan oleh (Rizqia, et. al., 2013), (Rahayu dan Asandimitra, 2014), (Mayogi, 2016), (Ochieng', 2016),
(Murekefu \& Ouma, 2012) yang menyatakan kebijakan dividen berpengaruh terhadap nilai perusahaan.

Kebijakan hutang tidak berpengaruh terhadap nilai perusahaan. Artinya, besarnya hutang yang digunakan tidak mempengaruhi nilai perusahaan. Tidak adanya pengaruh kebijakan hutang terhadap nilai perusahaan sesuai dengan teori yang dikemukakan oleh Modigliani and Miller's. MM menyatakan bahwa seberapapun besarnya penggunaan hutang tidak akan berpengaruh terhadap harga saham dan nilai perusahaan. Hal itu disebabkan oleh penggunaan hutang akan mengakibatkan biaya ekuitas naik dengan tingkat yang sama seperti tingkat pendapatan yang dihasilkan. Di pasar modal Indonesia, penciptaan nilai tambah perusahaan dapat juga disebabkan oleh faktor psikologis pasar. Investor tidak terlalu memperhatikan besar kecilnya hutang, tetapi lebih memperhatikan kebijakan manajemen menggunakan dana dari hutang dengan efektif dan efisien agar dapat menciptakan nilai tambah bagi perusahaan.

Hasil ini sejalan dengan penelitian (Putri \& Rachmawati, 2018) dan (Ayako \& Wamalwa, 2015) yang menyatakan kebijakan hutang tidak berpengaruh signifikan terhadap nilai perusahaan.

Hasil ini tidak sejalan dengan penelitian yang telah dilakukan oleh (Rizqia, et. al., 2013) yang menyatakan kebijakan hutang berpengaruh terhadap nilai perusahaan.

Hasil penelitian menunjukkan bahwa profitabilitas berpengaruh positif dan signifikan terhadap nilai perusahaan pada perusahaan sub sektor property dan real estate yang terdaftar di BEI periode 2012-2017. Berarti semakin tinggi ROE, maka nilai perusahaan akan meningkat. ROE menunjukkan efektivitas dalam menghasilkan tingkat keuntungan yang berasal dari operasi perusahaan atau laba netto sesudah pajak dengan modal sendiri.

Profitabilitas mampu mempengaruhi persepsi investor terhadap perusahaan mengenai prospek masa dating. Profitabilitas yang tinggi maka akan semakin tinggi juga minat investor untuk berinvestasi sebab adanya jaminan pengembalian atas modal sendiri yang akan dan telah diinvestasikan, sehingga membuat harga saham meningkat, dan menjadikan nilai perusahaan juga meningkat.

Hasil ini sejalan dengan penelitian yang telah dilakukan oleh (Prasetyorini, 2013), (Rizqia, et. al., 2013) yang menyatakan bahwa profitabilitas yang diukur menggunakan ROE berpengaruh signifikan terhadap nilai perusahaan.

Hasil ini tidak sejalan dengan penelitian yang telah dilakukan oleh (Palupi \& Hendiarto, 2018) dan (Rahayu dan Asandimitra, 2014) yang menyatakan profitabilitas tidak berpengaruh terhadap nilai perusahaan.

\section{KESIMPULAN}

Kesimpulan hasil penelitian ini adalah: (1) Kebijakan dividen yang diukur dengan DPR pada perusahaan property dan real estate periode 2012- 
2017 cenderung menurun. Kebijakan hutang diukur dengan DER, profitabilitas diukur dengan ROE, dan nilai perusahaan diukur dari PBV cenderung meningkat. (2) Secara simultan kebijakan dividen, hutang, dan profitabilitas berpengaruh signifikan terhadap nilai perusahaan sebesar $78,70 \%$. Profitabilitas memiliki pengaruh paling besar yaitu sebesar $48,10 \%$.

\section{DAFTAR PUSTAKA}

Ayako, A., \& Wamalwa, F. 2015. Determinants of Firm Value in Kenya: Case of Commercial Banks Listed at the Nairobi Securities Exchange. Applied Finance and Accounting, 1(2), 129. https://doi. org/10.11114/afa.v1i2.934

Darmadji, T. dan Hendy, M. F. 2012. Pasar Modal Indonesia: Pendekatan Tanya Jawab (3rd ed.). Salemba Empat.

Enebrand, A., \& Magnusson, T. 2018. Dividend Policy and its Impact on Firm Valuation. Jönköping International Business School, May, 1-46.

Gitman, L. J. and Zutter, C. J. 2015. Principle of Management Finance (Fourteen). Pearson Education Limited.

Husnan, S. dan Pudjiastuti, E. 2015. Dasar-dasar Manajemen Keuangan (7th ed.). UPP STIM YKPN.

Jusriani, I. F., \& Rahardjo, S. N. 2013. Analisis Pengaruh Profitabilitas, Kebijakan Deviden, Kebijakan Utang, Dan Kepemilikan Manajerial Terhadap Nilai Perusahaan (Studi Empiris Pada Perusahaan Manufaktur Yang Terdaftar Di Bursa Efek Indonesia Periode 2009 2011). Diponegoro Journal of Accounting, 2(2), 168-177.

Kasmir. 2015. Analisis Laporan Keuangan. PT. Raja Grafindo Persada.

LDN, S. 2019. Impact of Dividend Policy on Firm Performance Evidence From Listed Companies in Colombo Stock Exchange. Global Scientific Journals, 7(10), 225-239.

Mardiyati, U., Ahmad, G. N., Putri, R. 2012. Pengaruh Kebijakan Dividen, Kebijakan Hutang Dan Profitabilitas Terhadap Nilai Perusahaan Manufaktur Yang Terdaftar Di Bursa Efek Indonesia Periode 2015-2017. Jurnal Riset Manajemen Sains Indonesia (JRMSI), 3(1), 1-17. https://doi.org/10.35794/ emba.v8i4.30859

Mayogi, D. G. dan F. 2016. Pengaruh Profitabilitas, Ukuran Perusahaan Dan Kebijakan Dividen Terhadap Nilai Perusahaan. Jurnal Ilmu Dan Riset Akuntansi, 5(1), 1-18. https://doi.org/10.21776/ ub.profit.2020.014.02.9
Murekefu, T. M., \& Ouma, O. P. 2012. The relationship between dividend payout and firm performance: a study of listed companies in kenya. European Scientific Journal, 8(9), 199-215.

Ochieng', Y. S. 2016. The effect of dividend policy on the value of firms listed at the Nairobi securities exchange. November, 1-73.

Palupi, R. S., \& Hendiarto, S. 2018. Kebijakan Hutang, Profitabilitas dan Kebijakan Dividen Pada Nilai Perusahaan Properti \& Real Estate. Jurnal Ecodemica, 2(2), 177-185.

Prasetyorini, B. F. 2013. Pengaruh Ukuran Perusahaan, Leverage, Price Earning Ratio dan Profitabilitas terhadap Nilai Perusahaan. Jurnal Ilmu Manajemen (JIM), 1(1).

Putri, V. R., \& Rachmawati, A. 2018. The Effect of Profitability, Dividend Policy, Debt Policy, and Firm Age on Firm Value in The Non-Bank Financial Industry. Jurnal Ilmu Manajemen \& Ekonomika, 10(1), 14. https://doi.org/10.35384/jime.v10i1.59

Rahayu, F. D. dan Asandimitra, N. 2014. Pengaruh Ukuran Perusahaan, Leverage, Profitabilitas, Kebijakan Dividen Dan Cash Holding Terhadap Nilai Perusahaan Pada Sektor Manufaktur. Jurnal Ilmu Manajemen (JIM), 2(2), 548-561.

Rajesh, K. B. 2015. Determinants of value creation: An empirical examination from UAE market. International Journal of Economics and Financial Issues, 5(1), 75-85.

Rehman, O. U. 2016. Impact of Capital Structure and Dividend Policy on Firm Value. Journal of Poverty, Investment and Development, 21(2006), 40-57.

Riyanto, B. 2011. Dasar-dasar Pembelanjaan (4th ed.). BPFE-UGM.

Rizqia, D. A., Aisjah, S., \& Sumiati. 2013. Effect of Managerial Ownership , Financial Leverage, Profitability, Firm Size, and Investment Opportunity on Dividend Policy and Firm Value. Research Journal of Finance and Accounting, 4(11), 120-130.

Sofyaningsih, S. dan Hardiningsih, P. 2011. Struktur Kepemilikan, Kebijakan Dividen, Kebijakan Utang, dan Niali Perusahaan. Dinamika Keuangan \& Perbankan, 3(1).

Thi, N., Ha, L., \& Minh, B. T. 2018. Determinants of Firm Value in Vietnam: A Research Framework. International Journal of Science and Research, 9(1), 626-631. https://doi.org/10.21275/ART20204002

Yee, T. C. 2017. Dividend Pay-out Policy and Firm Performance. Journal of Arts \& Social Sciences, 1(1), 42-52.

www.idx.co.id 
Tabel 1. Perkembangan Kebijakan Dividen, Hutang, Profitabilitas, dan Nilai Perusahaan sektor property dan real estate yang terdaftar di Bursa Efek Indonesia (BEI) periode 2012-2017

\begin{tabular}{llrrrrrr}
\hline & Tahun & \multicolumn{1}{c}{2012} & \multicolumn{1}{c}{2013} & \multicolumn{1}{c}{2014} & \multicolumn{1}{c}{2015} & \multicolumn{1}{c}{2016} & \multicolumn{1}{c}{2017} \\
\hline Kebijakan & Rata-rata & $19,75 \%$ & $22,32 \%$ & $18,43 \%$ & $17,48 \%$ & $17,58 \%$ & $19,18 \%$ \\
Dividen & Maksimum & $43,00 \%$ & $56,28 \%$ & $49,00 \%$ & $34,00 \%$ & $49,16 \%$ & $40,27 \%$ \\
& Minimum & $6,02 \%$ & $5,55 \%$ & $6,18 \%$ & $6,78 \%$ & $5,01 \%$ & $6,98 \%$ \\
Kebijakan & Rata-rata & 1,02 & 1,04 & 1,08 & 0,94 & 0,92 & 0,86 \\
Hutang & Maksimum & 2,27 & 2,85 & 2,24 & 1,8 & 1,83 & 1,58 \\
& Minimum & 0,28 & 0,26 & 0,14 & 0,16 & 0,09 & 0,07 \\
Profitabilitas & Rata-rata & 16,43 & 13,12 & 10,51 & 12,05 & 7,32 & 11,09 \\
& Maksimum & 31,59 & 25,18 & 31,75 & 29 & 38,54 & 32,60 \\
& Minimum & 7,07 & 1,19 & 1,54 & 2,82 & 1,05 & 1,61 \\
Nilai & Rata-rata & 2,29 & 266 & 1,59 & 1,90 & 1,52 & 1,44 \\
& Maksimum & 3,54 & 3,59 & 4,1 & 5,62 & 5,9 & 7,53 \\
& Minimum & 0,62 & 1,72 & 0,47 & 0,33 & 0,15 & 0,16 \\
\hline
\end{tabular}

Tabel 2. Hasil Uji Hipotesis Simultan

\begin{tabular}{lrll}
\hline R-squared & 0.786981 & Mean dependent var & 1.653611 \\
Adjusted R-squared & 0.738011 & S.D. dependent var & 1.281751 \\
S.E. of regression & 0.656062 & Akaike info criterion & 2.167543 \\
Sum squared resid & 37.44633 & Schwarz criterion & 2.689069 \\
Log likelihood & -96.04734 & Hannan-Quinn criter. & 2.379003 \\
F-statistic & 16.07072 & Durbin-Watson stat & 1.277364 \\
Prob(F-statistic) & 0.000000 & & \\
\hline
\end{tabular}

Tabel 3. Hasil analisis regresi parsial

\begin{tabular}{ccccc}
\hline Variable & Coefficient & Std. Error & t-Statistic & Prob. \\
\hline C & 1.954770 & 0.324669 & 6.020809 & 0.0000 \\
DPR & -2.008363 & 0.856944 & -2.343633 & 0.8978 \\
DER & 0.045368 & 0.248466 & 0.182592 & 0.8555 \\
ROE & 2.291998 & 1.060696 & 0.275289 & 0.0047 \\
\hline
\end{tabular}

Tabel 4. Perhitungan Koefisien Determinasi Parsial

\begin{tabular}{|c|c|c|c|}
\hline Variabel & Nilai $^{b}$ & Zero Order & $\mathrm{r}^{2}$ \\
\hline Kebijakan Dividen & $-0,1676431426$ & 0,135205 & $-0,1116117$ \\
\hline Kebijakan Hutang & 0,0180542377 & 0,231299 & 0,4175927126 \\
\hline \multirow[t]{2}{*}{ Profitabilitas } & 0,01358357205 & 0,354111 & 0,4810092283 \\
\hline & $\mathrm{r}^{2}$ & & 0,786981 atau $78,70 \%$ \\
\hline
\end{tabular}

